\title{
Evidence for an Unusual Temperature Dependence of the Atmospheric Corrosion of Zinc
}

\author{
M. Esmaily, ${ }^{a, *, z}$ N. Mortazavi, ${ }^{\mathrm{b}}$ J. E. Svensson, ${ }^{\mathrm{a}, * *}$ and L. G. Johanssona \\ ${ }^{a}$ Department of Chemistry and Chemical Engineering, Chalmers University of Technology, \\ SE-41296 Gothenburg, Sweden \\ ${ }^{b}$ Department of Applied Physics, Chalmers University of Technology, SE-412 96 Gothenburg, Sweden
}

\begin{abstract}
The atmospheric corrosion behavior of zinc in the presence of $\mathrm{NaCl}$ has been investigated using well-controlled laboratory exposures in $95 \% \mathrm{RH}$ air at ten different temperatures in the range -4 to $22^{\circ} \mathrm{C}$. Results show that a critical temperature $\left(\sim-0.5^{\circ} \mathrm{C}\right)$ exists in zinc corrosion above which the rate of corrosion is constant/independent of temperature, and, below which there is a positive correlation between temperature and corrosion rate. The corrosion products formed above and below $-0.5^{\circ} \mathrm{C}$ are also entirely different. While simonkolleite, hydrozincite and zinc carbonate hydroxide are the main corrosion products at $\mathrm{T} \geq-0.5^{\circ} \mathrm{C}$, the same compounds are absent at $\mathrm{T}<-0.5^{\circ} \mathrm{C}$. Instead, sodium zinc carbonate $\left(\mathrm{Na}_{2} \mathrm{Zn}_{3}\left(\mathrm{CO}_{3}\right)_{4} \cdot 3 \mathrm{H}_{2} \mathrm{O}\right)$ is the dominant corrosion product at low temperature, together with $\mathrm{Na}_{2} \mathrm{ZnCl}_{4} \cdot 3 \mathrm{H}_{2} \mathrm{O}$ and sweetite $\left(\mathrm{Zn}(\mathrm{OH})_{2}\right)$. The results are interpreted in terms of two distinct corrosion modes prevailing at "high" and "low" temperature, respectively.

(C) The Author(s) 2016. Published by ECS. This is an open access article distributed under the terms of the Creative Commons Attribution Non-Commercial No Derivatives 4.0 License (CC BY-NC-ND, http://creativecommons.org/licenses/by-nc-nd/4.0/), which permits non-commercial reuse, distribution, and reproduction in any medium, provided the original work is not changed in any way and is properly cited. For permission for commercial reuse, please email: oa@electrochem.org. [DOI: 10.1149/2.0751614jes] All rights reserved.

(c)) BY-NC-ND
\end{abstract}

Manuscript submitted September 8, 2016; revised manuscript received October 31, 2016. Published November 8, 2016.

Zinc $(\mathrm{Zn})$ is used for galvanizing steel to mitigate corrosion. Also, rolled $\mathrm{Zn}(<1 \% \mathrm{Cu})$, die-cast $\mathrm{Zn}-\mathrm{Al}(4 \% \mathrm{Al})$, and brass $(\mathrm{Cu}+20-40 \%$ $\mathrm{Zn}$ ) have numerous applications in e.g., infrastructure and engineering sectors, ${ }^{1-4}$ where environmental degradation is often an issue. Thus, $\mathrm{Zn}$ corrosion has been studied by means of atmospheric corrosion exposures in the field, ${ }^{5-7}$ and in the laboratory, ${ }^{8-10}$ as well as, in the presence of an aqueous media using droplets, ${ }^{11,12}$ and bulk electrolyte exposures. ${ }^{13}$ Various aspects of $\mathrm{Zn}$ corrosion have been studied in the works cited above and other reports.

When zinc is exposed to the atmosphere in the presence of chloride, the main corrosion products are reported to be simonkolleite $\left(\mathrm{Zn}_{5}(\mathrm{OH})_{8} \mathrm{Cl}_{2} \mathrm{H}_{2} \mathrm{O}\right)$ and hydrozincite $\left(\mathrm{Zn}_{5}\left(\mathrm{CO}_{3}\right)_{2}(\mathrm{OH})_{6}\right){ }^{14-18} \mathrm{Zinc}$ hydroxy sulfates, e.g., $\mathrm{ZnSO}_{4} 3 \mathrm{Zn}(\mathrm{OH})_{2} \cdot 4 \mathrm{H}_{2} \mathrm{O}$, often occur in environments containing traces of $\mathrm{SO}_{2} \cdot{ }^{19}$ There are studies examining the importance of cations in the salt-induced atmospheric corrosion of $\mathrm{Zn}$. For instance, Lindström et al. ${ }^{21}$ studied the corrosivity of chloride and sulfate salts toward $\mathrm{Zn}$ at $22^{\circ} \mathrm{C}$ and noted that sodium-containing salts were much more corrosive compared to salt containing e.g., $\mathrm{Mg}^{+}, \mathrm{Zn}^{2+}$, and $\mathrm{NH}^{+}{ }_{4}$. Similarly, Sanyal et al. ${ }^{20}$ examined the atmospheric corrosion of $\mathrm{Zn}$ at $40^{\circ} \mathrm{C}$ and $85 \%$ relative humidity (RH) in the presence of different salts. Thomas et al. ${ }^{22-26}$ have investigated the $\mathrm{Zn}$ corrosion as a function of $\mathrm{pH}$ in $\mathrm{NaCl}(a q)$ solution, ${ }^{22}$ reported on the corrosion layers/products formed in contact with a seawater droplet, ${ }^{23}$ and reported on the occurrence of the oxygen reduction reaction (ORR) on Zn oxide. ${ }^{24-26}$ And finally, studies have shown that the role played by the microstructure is vital in the case of $\mathrm{Zn}$ alloycoated steels. ${ }^{27-30}$ As an example, Prosek et al. ${ }^{27}$ reported that a finer microstructure resulted in better corrosion resistance in $\mathrm{Zn}-5 \mathrm{Al}$ and $\mathrm{Zn}-3 \mathrm{Al}-2 \mathrm{Mg}$ alloys and attributed this to a rapid blocking of cathodic sites.

While all the above-mentioned studies have been performed at ambient temperature or higher, $\mathrm{Zn}$ is often subjected to corrosive conditions at temperatures below ambient. For example, because of the use of de-icing salt $(\mathrm{NaCl})$ on the roads during winter in temperate and cold regions of the world, car bodies made of $\mathrm{Zn}$-coated (galvanized) steel are subjected to $\mathrm{NaCl}$-induced atmospheric corrosion at temperatures close to or below $0^{\circ} \mathrm{C}$.

Because the anodic and cathodic reactions and electrolytic conductivity are all thermally activated processes, ${ }^{31-33}$ the rate of electrochemical corrosion usually increases with temperature. In atmo-

\footnotetext{
*Electrochemical Society Student Member.

**Electrochemical Society Member.
}

${ }^{z}$ E-mail: mohsen.esmaily@ chalmers.se spheric corrosion, gases that are adsorbed on surfaces or dissolved in the surface electrolyte play important roles, i.e., as oxidants $\left(\mathrm{O}_{2}\right)$ or by reacting with the surface film $\left(\mathrm{SO}_{2}, \mathrm{CO}_{2}\right)$. Because gas adsorption and gas dissolution are exothermic processes, the equilibrium concentration of dissolved and adsorbed gases increases with decreasing temperature. This may cause an inverse dependence of the rate of atmospheric corrosion on temperature in some cases. Thus, Niklasson et al. ${ }^{34}$ reported that the corrosion of lead exhibited a negative correlation with temperature in the presence of gaseous acetic acid. Esmaily et al. ${ }^{35}$ showed that there was no clear correlation between temperature and the rate of atmospheric corrosion of $\mathrm{Mg}$ in the presence of $\mathrm{NaCl}$.

Few studies report on the role of temperature in the atmospheric corrosion of $\mathrm{Zn}$. Svensson et al. ${ }^{36}$ reported an inverse temperaturedependence for the atmospheric corrosion of $\mathrm{Zn}$ in the presence of traces of $\mathrm{SO}_{2}$ in the range $4-20^{\circ} \mathrm{C}$, the highest corrosion rate being registered at the lowest temperature. According to Henriksen et al., ${ }^{37}$ $\mathrm{Zn}$ suffered corrosion in an outdoor environment (the northern parts of Norway) at temperatures well below $0{ }^{\circ} \mathrm{C}$. The authors ${ }^{37}$ provided no details on the corrosion mechanism and corrosion products' composition at $\mathrm{T}<0^{\circ} \mathrm{C}$. Thus, there is no systematic study of $\mathrm{Zn}$ corrosion at temperatures $<0^{\circ} \mathrm{C}$.

To fill this gap, the present paper investigates the $\mathrm{NaCl}$-induced atmospheric corrosion behavior of $\mathrm{Zn}$ in the range -4 to $22^{\circ} \mathrm{C}$ using a newly developed corrosion set-up that enables us to reliably examine the effect of temperature on the atmospheric corrosion of metals. ${ }^{38}$ This study was done to advance the understanding of the $\mathrm{Zn}$ corrosion in real-world atmospheric environments, where the metal may experience significant temperature variations.

\section{Materials and Methods}

Sample preparation.-Electrolytic grade zinc (Zn (99.95\% purity) was machined to obtain $15 \times 15 \times 3 \mathrm{~mm}^{3}$ coupons. Samples were ground using SiC grit papers (P1000 to P4000 mesh). Polishing was performed using diamond paste $(0.25-3 \mu \mathrm{m})$. The amount of $\mathrm{NaCl}$ added to the surface, by spraying of a $\mathrm{NaCl}$-containing solution of $80 / 20$ ethanol/water, ${ }^{39}$ was 14 or $70 \mu \mathrm{g} / \mathrm{cm}^{2}$. Care was taken to achieve an even distribution of $\mathrm{NaCl}$ on the sample surface (Fig. 1). The salt particles (in Fig. 1) ranged widely in size, from $\sim 0.05$ to $30 \mu \mathrm{m}$.

Experimental set-up (Corrosion exposures).- The exposure setup is described elsewhere. ${ }^{39}$ The gas flow in the chambers was 1000 $\mathrm{ml} / \mathrm{min}$ corresponding to an average flow velocity of $1 \mathrm{~mm} / \mathrm{s}$. Relative 


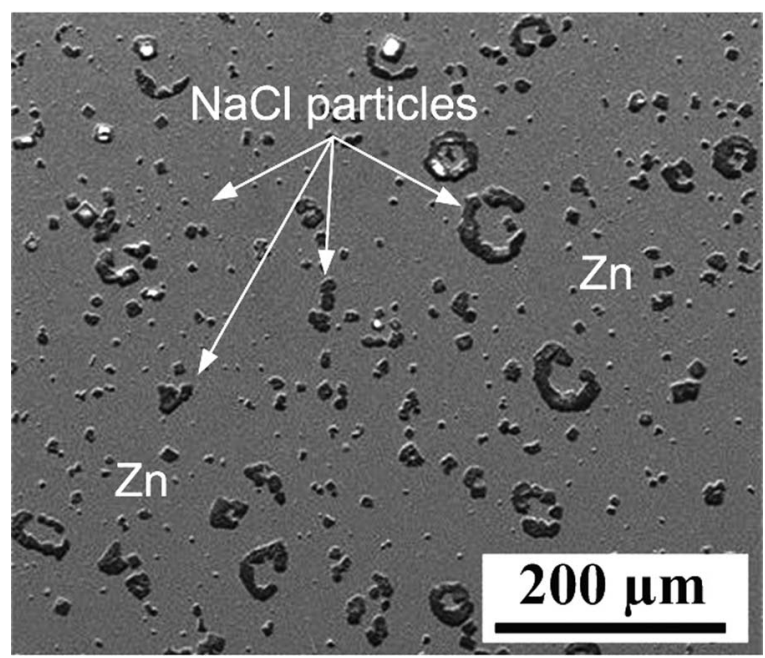

Figure 1. A SEM image showing an even distribution of $\mathrm{NaCl}$ particles on the surface of $\mathrm{Zn}$.

humidity $(\mathrm{RH})$ was regulated to be $95 \pm 0.3 \%$. $\mathrm{CO}_{2}$ concentration was $400 \pm 20 \mathrm{ppm}$. Exposures were performed at a wide range of temperatures $\left(-4\right.$ to $\left.22^{\circ} \mathrm{C}\right)$ with an overall accuracy of $\pm 0.08-0.12^{\circ} \mathrm{C}$.

Gravimetric measurement.-Pickling was performed to determine the metal losses. Thus, water-soluble corrosion products were first removed by leaching in Milli-Q water. Afterwards, the samples were pickled several times in a saturated ammonium acetate $\left(\mathrm{NH}_{4} \mathrm{C}_{2} \mathrm{H}_{3} \mathrm{O}_{2}\right)$ solution (at $\left.22^{\circ} \mathrm{C}\right)$ until constant masses were registered. Self-corrosion during pickling was negligible.

Methods of analysis.-Corrosion products were studied using X-ray diffraction (XRD). XRD data were taken both by BraggBrentano (the normal mode) and grazing incidence (GIXD) angle geometries. The amount of water-soluble anions in the corrosion products was determined by the ion chromatography (IC) method using a Dionex 1000 equipped with an Ionpac AD4-SC Analytic Column. The eluent was $1.8 \mathrm{mM} \mathrm{Na}_{2} \mathrm{CO}_{3} / 1.7 \mathrm{mM} \mathrm{NaHCO}$.

Corrosion products were viewed using an FEI Quanta 200 environmental scanning electron microscopy (ESEM). Imaging was performed using secondary electrons (SE) and backscattered electrons (BSE). The instrument was equipped with Oxford Inca energy dispersive X-ray detector (EDX) system, with a beryllium window, that makes the quantification of carbon content in the corrosion products reliable.

To delineate the chemical composition of the thin oxide layer(s), we employed scanning transmission electron microscopy (STEM) and high-resolution Auger electron spectroscopy (HR-AES). The STEM analyses were performed in a Titan 80 instrument, equipped with an Oxford Inca EDX detector, operating at $300 \mathrm{kV}$. HR-AES depth profiling was performed in a site-specific manner (on an area of 200 $\times 200 \mathrm{~nm}^{2}$ ) using a Physical Electronics Model 710 scanning auger nanoprobe (LS) equipped with a spherical sector analyzer. AES spectra were recorded in direct mode with a $2-5 \mathrm{keV}$ and $1 \mathrm{nA}$ primary beam, a depth resolution of $\sim 1.5 \mathrm{~nm}$, an elemental sensitivity down to 0.1 (in at. \%) and a rather high lateral resolution of $\sim 6 \mathrm{~nm}$.

We employed focused ion beam (FIB) milling method (using an FEI Versa 3D combined FIB/SEM workstation) to; $(a)$ prepare cross sections through the corrosion products and metal substrate and also (b) to create site-specific in-situ lift-outs for the STEM analyses. This latter procedure ${ }^{39}$ consists of several main steps; platinum $(\mathrm{Pt})$ deposition with the aid of electrons and ions for protection, coarse ion milling (bulk-out), U-cut, lift out, mounting on a copper grid, thinning and finally a cleaning procedure.
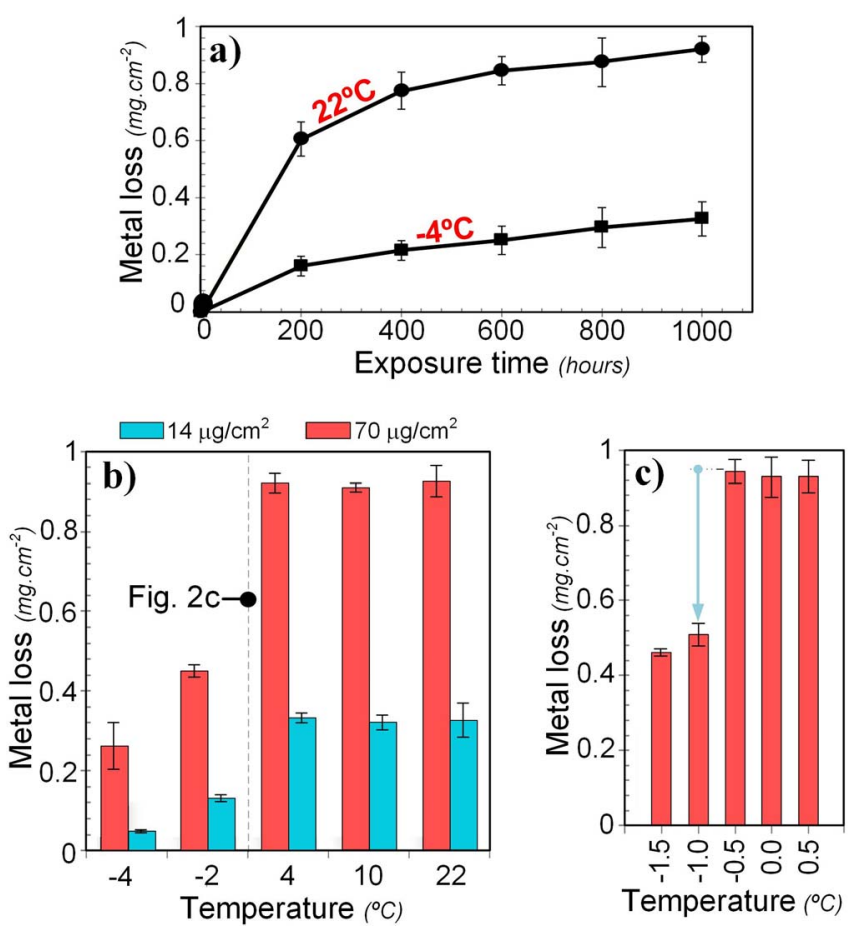

Figure 2. Corrosion of zinc as a function of time and temperature | (a) Metal loss at $200 \mathrm{~h}<\mathrm{t}<1000 \mathrm{~h}$ at 22 and $-4{ }^{\circ} \mathrm{C}$ (in the presence of $70 \mu \mathrm{g} / \mathrm{cm}^{2}$ $\mathrm{NaCl}$ ), (b) metal loss after $1000 \mathrm{~h}$ at $-4,-2,4,10$ and $22^{\circ} \mathrm{C}$ at two levels of $\mathrm{NaCl}$, and (c) metal loss of $\mathrm{Zn}$ after $1000 \mathrm{~h}$ at $0.5,0.0,-0.5,-1.0$, and $-1.5 \mathrm{v}$ in the presence of $70 \mu \mathrm{g} / \mathrm{cm}^{2} \mathrm{NaCl}$. All experiments were carried out in $95 \%$ $\mathrm{RH}$ air containing $400 \mathrm{ppm} \mathrm{CO}_{2}$.

\section{Results}

Gravimetric measurements.-Figure 2a presents metal losses of $\mathrm{Zn}$ in the presence of $\mathrm{NaCl}$ at 22 and $-4^{\circ} \mathrm{C}$ in $95 \% \mathrm{RH}$ air containing $400 \mathrm{ppm} \mathrm{CO}_{2}$ as a function of exposure time. Initially, corrosion was considerably faster at $22^{\circ} \mathrm{C}$ compared to $-4^{\circ} \mathrm{C}$. However, the rates of corrosion were almost the same during later stages $(>600 \mathrm{~h})$. Figure $2 \mathrm{~b}$ shows the metal loss after $1000 \mathrm{~h}$ exposure at $-4,-2,4,10$ and $22^{\circ} \mathrm{C}$ at two levels of added $\mathrm{NaCl}$. The corrosion of the reference samples (exposed in the absence of salt) was negligible $\left(<0.02 \mathrm{mg} / \mathrm{cm}^{2}\right.$ after 1000 h). Finally, Fig. 2c shows metal loss after 1000 h exposure at $-1.5,-1.0,-0.5,0.0$ and $0.5^{\circ} \mathrm{C}$.

Hence, corrosion rate is independent of temperature in the range $-0.5-22^{\circ} \mathrm{C}$. This is in accordance with Lindström et al., ${ }^{21}$ who studied the corrosion of $\mathrm{Zn}$ in the temperature range $4-40^{\circ} \mathrm{C}$. Also, the corrosion rates measured in the range $-0.5-22^{\circ} \mathrm{C}$, with metal losses after $1000 \mathrm{~h}$ of $\sim 0.9$ and $0.34 \mathrm{mg} / \mathrm{cm}^{2}(\sim 10.8$ and $4.1 \mu \mathrm{m} /$ year $)$ at 70 and $14 \mu \mathrm{g} / \mathrm{cm}^{2} \mathrm{NaCl}$, respectively. In contrast, the present study shows that the rate of corrosion decreased rapidly below $-0.5^{\circ} \mathrm{C}$, the mass losses registered at $-1.0,-1.5$ and $-2.0^{\circ} \mathrm{C}$ being about $50 \%$ of those measured in the range $-0.5-22^{\circ} \mathrm{C}$. Lowering the exposure temperature to $-4^{\circ} \mathrm{C}$ resulted in a further decrease in corrosion rate to about $25 \%$ of the level observed at $-0.5^{\circ} \mathrm{C}$ and higher. The same trend was observed for the mass gains (not shown). The temperature dependence of $\mathrm{Zn}$ corrosion did not depend on the amount of salt added.

Corrosion product composition.-XRD analysis was performed on some selective samples exposed at six different temperatures, three above and three below the "critical" temperature $\left(-0.5^{\circ} \mathrm{C}\right.$, see Fig. 2). Figure 3 shows two representative XRD patterns (both BraggBrentano and GIXD configurations) acquired from two specimens exposed $-4^{\circ} \mathrm{C}$ (below the critical $\mathrm{T}$ ) and $22^{\circ} \mathrm{C}$ (above the critical $\mathrm{T}$ ). The same crystalline corrosion products were identified after exposure at $-0.5^{\circ} \mathrm{C}$ and above. The diffraction pattern in Fig. 3a 

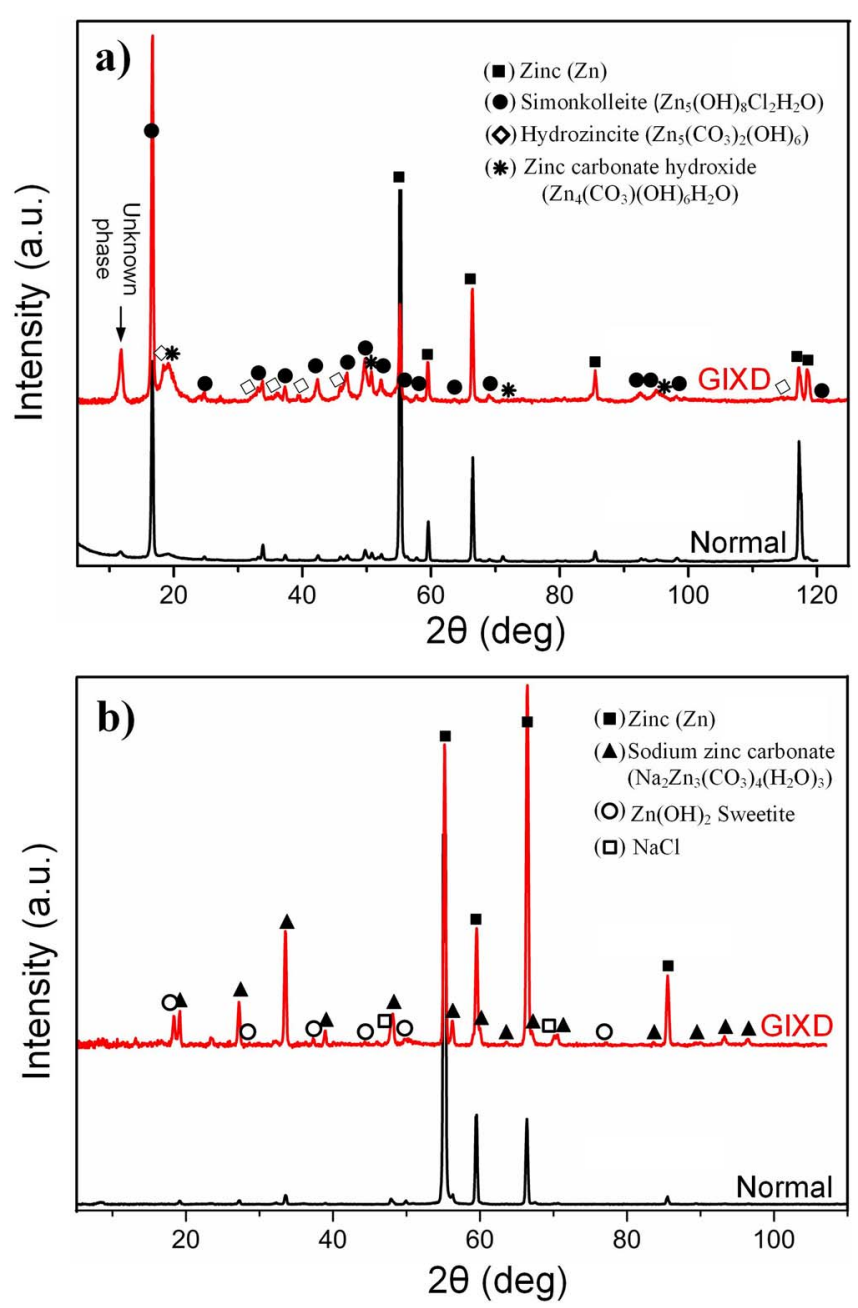

Figure 3. XRD diffraction patterns of $\mathrm{Zn}$ after $1000 \mathrm{~h}$ in $95 \% \mathrm{RH}$ air in the presence of $70 \mu \mathrm{g} / \mathrm{cm}^{2} \mathrm{NaCl}$ (a) $22^{\circ} \mathrm{C}$, (b) $-4 \mathrm{v}$. $\mathrm{Cr} \mathrm{K} \alpha$ radiation $(\lambda=2.29 \AA)$ was used.

was recorded after exposure at $22^{\circ} \mathrm{C}$ and showed that simonkolleite, $\left(\mathrm{Zn}_{5}(\mathrm{OH})_{8} \mathrm{Cl}_{2} \cdot \mathrm{H}_{2} \mathrm{O}\right)$, was the dominant corrosion product. In addition, traces of hydrozincite, $\mathrm{Zn}_{5}\left(\mathrm{CO}_{3}\right)_{2}(\mathrm{OH})_{6}$, and another zinc hydroxy carbonate, $\mathrm{Zn}_{4}\left(\mathrm{CO}_{3}\right)(\mathrm{OH})_{6} \mathrm{H}_{2} \mathrm{O}$ were detected. In some cases, the diffractograms contained an additional weak peak at $2 \theta=12^{\circ}$ that could not be attributed to a known compound. Hydrozincite and $\mathrm{Zn}_{4}\left(\mathrm{CO}_{3}\right)(\mathrm{OH})_{6} \mathrm{H}_{2} \mathrm{O}$ were detected in the GIXD mode (Fig. 3a).

It was notable that none of the corrosion products identified by $\mathrm{XRD}$ at $-0.5^{\circ} \mathrm{C}$ and higher were detected after exposure at $-1^{\circ} \mathrm{C}$ and lower. Instead, the dominant crystalline corrosion product was sodium zinc carbonate hydrate $\mathrm{Na}_{2} \mathrm{Zn}_{3}\left(\mathrm{CO}_{3}\right)_{4}\left(\mathrm{H}_{2} \mathrm{O}\right)_{3}$ together with small amounts of sweetite; (a tetragonal form of $\left.\mathrm{Zn}(\mathrm{OH})_{2}\right)$. $\mathrm{NaCl}$ was identified by XRD after $1000 \mathrm{~h}$ at -2 and $-4{ }^{\circ} \mathrm{C}$, but not at $4-22^{\circ} \mathrm{C}$, showing that, at low temperature, a significant fraction of the added $\mathrm{NaCl}$ remained unreacted after $1000 \mathrm{~h}$.

The SEM micrographs in Fig. 4 show that exposure at 22 and $-4^{\circ} \mathrm{C}$ resulted in entirely different corrosion morphologies. In agreement with the gravimetric results (Fig. 2) the samples exposed at $22^{\circ} \mathrm{C}$ showed more evidence for corrosion than at $-4^{\circ} \mathrm{C}$. Indeed, part of the metal surface appeared un-corroded after $1000 \mathrm{~h}$ exposure at $-4^{\circ} \mathrm{C}$, see e.g., Fig. 4f. At $22^{\circ} \mathrm{C}$, the corrosion products tended to form porous aggregates consisting of needlelike crystals covering the whole metal surface, while the corrosion products formed at $-4^{\circ} \mathrm{C}$ were denser.

In accordance with the XRD results, unreacted $\mathrm{NaCl}$ was detected by SEM/EDX after exposure at $-4^{\circ} \mathrm{C}$, but not at higher temperatures, e.g., 22,10 and $4{ }^{\circ} \mathrm{C}$. The fraction of the surface covered by unreacted salt $(f s)$ was determined by SEM/EDX in a $2 \mathrm{~mm}^{2}$ area. The highest $f s$ values were found at the lowest exposure temperature, image analysis showing that $\mathrm{NaCl}$ crystals covered $2.9 \%$ of the surface after $1000 \mathrm{~h}$ at $-4^{\circ} \mathrm{C}$.

The fraction of water-soluble chloride on samples contaminated with $70 \mu \mathrm{g} / \mathrm{cm}^{2} \mathrm{NaCl}$ was determined by IC after $1000 \mathrm{~h}$ exposure at 22 and $-4^{\circ} \mathrm{C}$. On the samples exposed at $22^{\circ} \mathrm{C}$ only $0.5 \%$ of the added chloride was leached by water, while the leachable fraction at $-4^{\circ} \mathrm{C}$ was $38 \%$. Thus, nearly all the chloride added was incorporated in the corrosion products in insoluble form after exposure at $22^{\circ} \mathrm{C}$. The XRD analysis of the corrosion products implies that much of the insoluble chloride was present in the form of simonkolleite. Conversely, the high fraction of water leachable chloride at $-4^{\circ} \mathrm{C}$ is in line with the absence of simonkolleite at that temperature.

Table I lists SEM/EDX analyses of the points indicated in Figs. 4a, 4b and 4d. Points 1 and 4 are low in $\mathrm{Zn}$ and high in sodium, oxygen and carbon. Point 1 has a composition very close to $\mathrm{Na}_{2} \mathrm{CO}_{3}$ and is thus identified as sodium carbonate. For position 4 the $\mathrm{Na} / \mathrm{C}$ ratio is somewhat lower, suggesting the presence of both carbonate and hydrogen carbonate (e.g., $\mathrm{Na}_{3} \mathrm{CO}_{3} \mathrm{HCO}_{3} \cdot 2 \mathrm{H}_{2} \mathrm{O}$ ). While sodium carbonate is expected to be present in hydrated form on the corroding sample i.e., as $\mathrm{Na}_{2} \mathrm{CO}_{3} \cdot 10 \mathrm{H}_{2} \mathrm{O}$, the water of hydration tends to be lost during dry storage and, especially, in the vacuum of the SEM. This explains why the analysis of point 1 corresponds to the anhydrous compound. Also, the lack of evidence for sodium carbonate and sodium carbonate hydrate by XRD is tentatively attributed to decomposition of the hydrated compound into poorly crystalline anhydrous (or amorphous) phases.

The composition at point $2\left(22^{\circ} \mathrm{C}\right)$ is close to that expected for simonkolleite $\left(\mathrm{Zn}_{5}(\mathrm{OH})_{8} \mathrm{Cl}_{2} \cdot \mathrm{H}_{2} \mathrm{O}\right)$ which was the dominant crystalline corrosion product at $22^{\circ} \mathrm{C}$ according to XRD. Point $3\left(-4^{\circ} \mathrm{C}\right)$, which appears as bright regions in Fig. 4d, exhibits an elemental ratio close to $\mathrm{Na}: \mathrm{Zn}: \mathrm{Cl}: \mathrm{O}=2: 1: 4: 3$ (Table I), corresponding to the compound $\mathrm{Na}_{2} \mathrm{ZnCl}_{4} \cdot 3 \mathrm{H}_{2} \mathrm{O}$ which was not identified by XRD, however. Finally, point $5\left(-4^{\circ} \mathrm{C}\right)$, and similar regions, had a composition close to sodium zinc carbonate, which was the main corrosion product at -2 and $-4^{\circ} \mathrm{C}$ according to XRD. It may be noted that the presence of a $\mathrm{Zn}$ background signal and of additional carbon due to handling are likely to slightly offset the EDX analysis of the corrosion product from the "true" values.

Figure 5 shows SEM/STEM/EDX results of FIB-prepared specimens. In accordance with the identification of simonkolleite after exposure at $22^{\circ} \mathrm{C}$ by XRD and plan view SEM/EDX, Fig. 5a shows a corrosion product agglomeration formed at $22^{\circ} \mathrm{C}$ with a composition close to that of simonkolleite. Figure 5b shows a cross section of a sample after $1000 \mathrm{~h}$ at $-4{ }^{\circ} \mathrm{C}$, exhibiting a relatively small corrosion product agglomeration. The composition (Fig. 5b) corresponds to $\mathrm{Na}_{2} \mathrm{Zn}_{3}\left(\mathrm{CO}_{3}\right)_{4} \cdot 3 \mathrm{H}_{2} \mathrm{O}$, which was detected both by XRD and plan view SEM/EDX (see Fig. 3, Table I). The corrosion product agglomeration is surrounded by regions dominated by $\mathrm{Na}, \mathrm{C}$ and $\mathrm{O}$ showing a chemical composition similar to point 4 in Table I, corresponding to sodium carbonate and sodium hydrogen carbonate.

Figures $5 \mathrm{c}$ and $5 \mathrm{~d}$ shows STEM micrographs of samples exposed at 22 and $-4{ }^{\circ} \mathrm{C}$, this time illustrating the relatively even corrosion product layers that in both cases covered much of the surface. Again, the morphology and composition of the corrosion product at the two temperatures is very different. At $22^{\circ} \mathrm{C}$, the layered corrosion product had a thickness in the range 0.8 to $1.5 \mu \mathrm{m}$ (Fig. 5c). Its top part was porous and dominated by large blade-like crystallites. Based on the XRD analysis (Fig. 4) and the SEM/EDX cross section analysis (Fig. $5 \mathrm{a})$, it is concluded that this layer consists of simonkolleite. Further down into the corrosion product there is an abrupt transition to a more compact region. A closer inspection revealed that the bottom "compact layer" had an internal structure and that a thin sub-layer could be identified closest to the $\mathrm{Zn}$ substrate which was even denser than the rest. The very dense, bottom part of the corrosion product is termed "barrier oxide" in Fig. 5c.

The compact middle and bottom layers contained only $\mathrm{Zn}$ and $\mathrm{O}$, with a ratio close to $\mathrm{Zn}: \mathrm{O}=1$, indicating zincite $(\mathrm{ZnO})$. To summarize, 

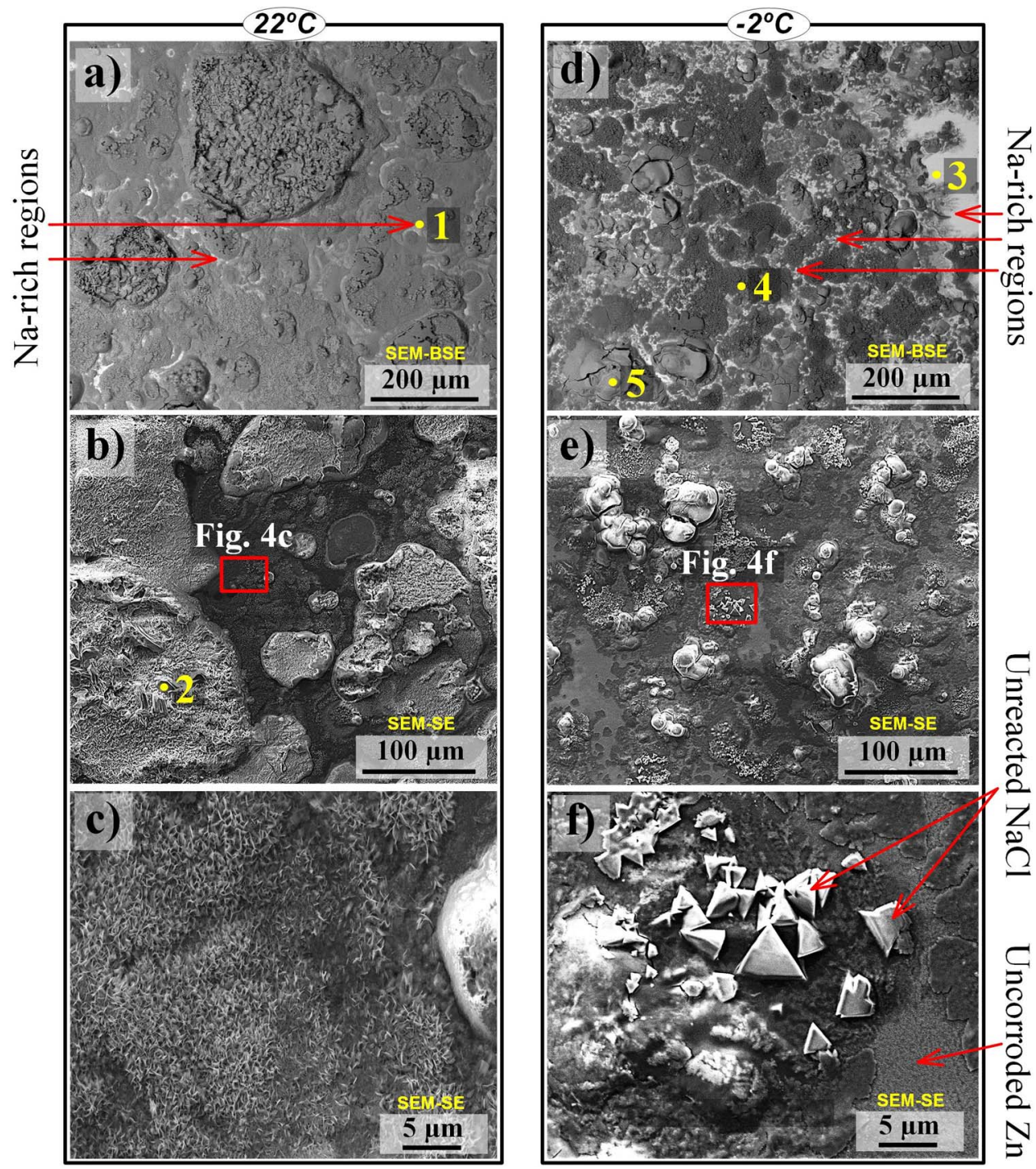

Figure 4. SE and BSE SEM micrographs showing the corrosion morphology at $22^{\circ} \mathrm{C}\left(\mathrm{a}, \mathrm{b}\right.$ and c) and $-4^{\circ} \mathrm{C}(\mathrm{d}$, e and $\mathrm{f})$ after $1000 \mathrm{~h}$ exposure in the presence of $400 \mathrm{ppm} \mathrm{CO} 2$ and $95 \% \mathrm{RH}$ and $70 \mu \mathrm{g} / \mathrm{cm}^{2} \mathrm{NaCl}$. The chemical compositions of the points designated 1 to 5 are listed in Table I.

the corrosion product formed at $22^{\circ} \mathrm{C}$ consisted of a top simonkolleite layer, a middle $\mathrm{ZnO}$ layer and a bottom $\mathrm{ZnO}$ barrier layer. It may be noted that STEM/EDX revealed local $\mathrm{Cl}$ enrichments beneath the $\mathrm{ZnO}$ barrier layer, being associated with nano-sized pits in the metal substrate, see Fig. 5c.

Exposure at $-4^{\circ} \mathrm{C}$ produced a single, continuous, and very dense, 200-400 $\mathrm{nm}$ thick layer on the $\mathrm{Zn}$ surface. The layer shown in Fig. $5 \mathrm{~d}$ is about $450 \mathrm{~nm}$. The STEM/EDX analyses were consistent with $\mathrm{Na}_{2} \mathrm{Zn}_{3}\left(\mathrm{CO}_{3}\right)_{4}\left(\mathrm{H}_{2} \mathrm{O}\right)_{3}$ which was detected both by XRD and by SEM/EDX (see above). Interestingly, the layer contained significant amounts of chlorine, the $\mathrm{Cl}$ concentration increasing as the $\mathrm{Zn}$ surface was approached. The $\mathrm{Cl}$ gradient was almost linear and is shown in Fig. 5e. Similar to the $22^{\circ} \mathrm{C}$ sample, local $\mathrm{Cl}$ enrichments were detected at the alloy/corrosion product interface, associated with nanometer size pits in the metal substrate, see Fig. $5 \mathrm{~d}$.

These regions were very high in $\mathrm{Cl}$ (reaching 48-52 at. \%) and Zn (28-32 at. \%) with only small amounts of oxygen and no sodium, suggesting the presence of $\mathrm{ZnCl}_{2} \cdot \mathrm{H}_{2} \mathrm{O}$. Figure $5 \mathrm{c}$ reveals, tentatively,

\begin{tabular}{|c|c|c|c|c|c|c|}
\hline Point & $\mathrm{Zn}$ & $\mathrm{C}^{*}$ & $\mathrm{O}$ & $\mathrm{Cl}$ & $\mathrm{Na}$ & Matching compounds \\
\hline 1 & $1 \pm 0.2$ & $15.1 \pm 1.8$ & $52.5 \pm 1.2$ & - & $31.5 \pm 0.5$ & $\mathrm{Na}_{2} \mathrm{CO}_{3}$ \\
\hline 2 & $30.2 \pm 1.3$ & $2.1 \pm 1.5$ & $56.7 \pm 0.4$ & $11 \pm 0.42$ & - & $\mathrm{Zn}_{5}(\mathrm{OH})_{8} \mathrm{Cl}_{2} \mathrm{H}_{2} \mathrm{O}$ \\
\hline 3 & $11.8 \pm 1.6$ & $1.4 \pm 1.9$ & $28.6 \pm 0.3$ & $39.5 \pm 0.6$ & $18.7 \pm 0.3$ & $\mathrm{Na}_{2} \mathrm{ZnCl}_{4} \cdot 3 \mathrm{H}_{2} \mathrm{O}$ \\
\hline 4 & $2.5 \pm 0.7$ & $15.7 \pm 2.1$ & $56.2 \pm 0.3$ & - & $25.6 \pm 1.5$ & $\begin{array}{l}\mathrm{Na}_{2} \mathrm{CO}_{3} \\
\mathrm{NaCO}_{3} \mathrm{HCO}_{3} \cdot 2 \mathrm{H}_{2} \mathrm{O}\end{array}$ \\
\hline 5 & $10.4 \pm 0.83$ & $19 \pm 3.6$ & $61.2 \pm 0.5$ & $0.1 \pm 2.1$ & $9.3 \pm 0.45$ & $\mathrm{Na}_{2} \mathrm{Zn}_{3}\left(\mathrm{CO}_{3}\right)_{4} \cdot 3 \mathrm{H}_{2} \mathrm{O}$ \\
\hline
\end{tabular}

*The analysis for carbon was done using a SEM equipped with a beryllium window. 

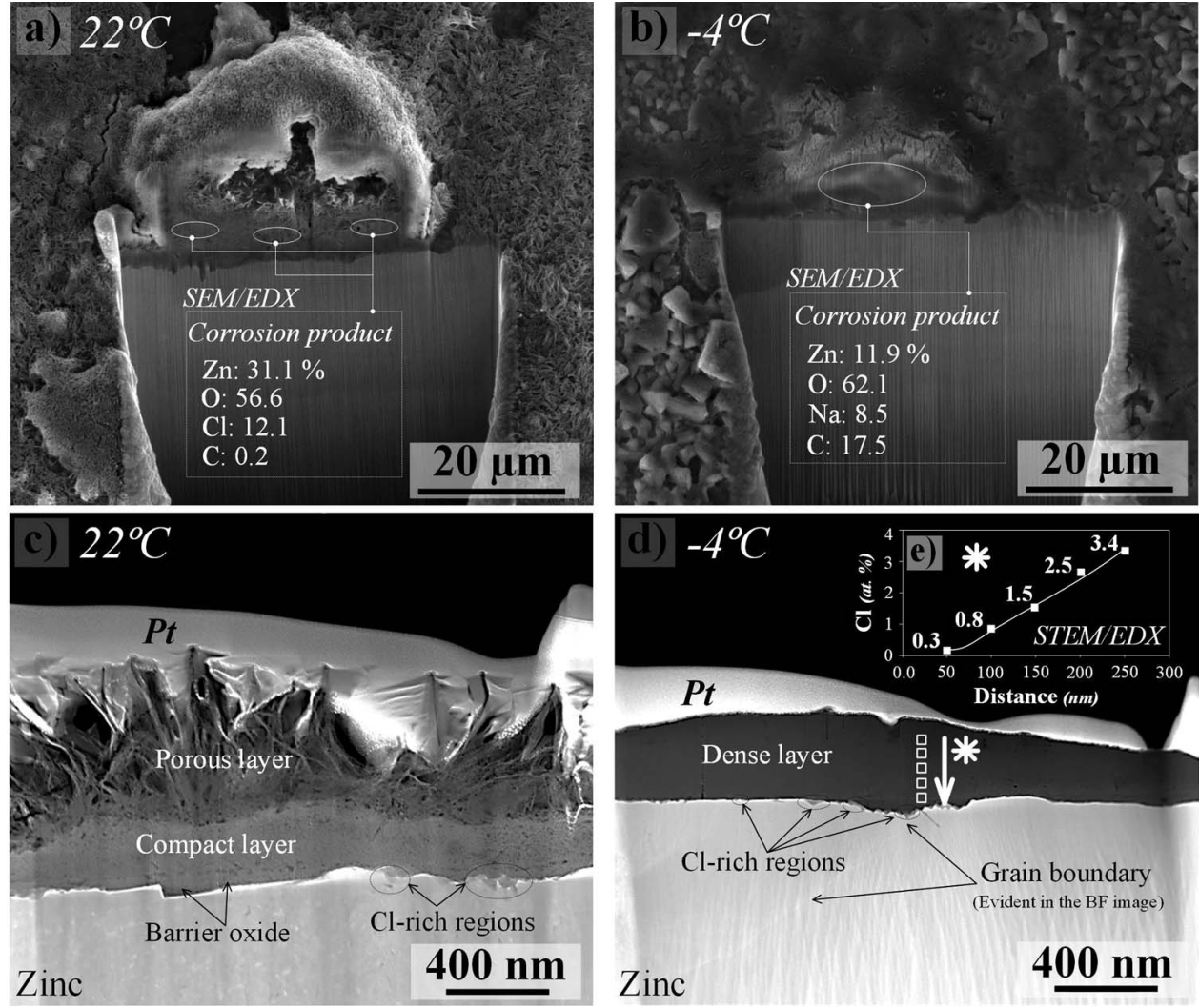

Figure 5. FIB/SEM/STEM/EDX investigation of $\mathrm{Zn}$ after corrosion at -4 and $22^{\circ} \mathrm{C} \mid$ (a and b) SEM backscattered electron images of specimens exposed at; a) $22^{\circ} \mathrm{C}$, b) $-4{ }^{\circ} \mathrm{C}$. The elemental compositions (by EDX) are in at.\%, and (c - e) STEM micrographs and EDX analysis; (c) at $22^{\circ} \mathrm{C}$, (d) at $-4{ }^{\circ} \mathrm{C}$, and (e) EDX analysis showing the $\mathrm{Cl}$ concentration in the corrosion product layer at $-4^{\circ} \mathrm{C}$ as a function of the distance to the surface of the corrosion product film. The samples were exposed for $1000 \mathrm{~h}$ at $95 \% \mathrm{RH}$ in the presence of $70 \mu \mathrm{g} / \mathrm{cm}^{2} \mathrm{NaCl}$ and $400 \mathrm{ppm} \mathrm{CO} 2$.

preferential corrosion of a metal grain boundary. The grain boundary was also observed in bright field (BF) STEM micrographs of the same area (not shown).

In order to investigate the transition between the corrosion behavior of $\mathrm{Zn}$ at high and low temperature (Fig. 2), HR-AES compositional depth profiling was carried out on specimens exposed for 10 and $100 \mathrm{~h}$ at -0.5 and $-1{ }^{\circ} \mathrm{C}$, see Fig. 6. In all cases (Figs. 6a$6 \mathrm{e})$, the analysis reached to the metal substrate as evidenced by the $\mathrm{Zn}$ signal approaching 100 at. \%. Due to surface contamination, the top $(\sim 2 \mathrm{~nm})$ of the surface film was high in carbon on all samples.

Figure 6 shows that the sudden transition between the faster high temperature corrosion at -0.5 and the slower corrosion at $-1.0^{\circ} \mathrm{C}$ (compare Fig. 2) is accompanied by a complete change in the corrosion product composition. Thus, the results show that while $\mathrm{ZnO}$ is a major constituent of the surface film formed at $-0.5^{\circ} \mathrm{C}$ (Figs. 6a and $6 \mathrm{~b}$ ), $\mathrm{ZnO}$ is absent at $-1.0^{\circ} \mathrm{C}$ (Figs. 6c-6e). After $10 \mathrm{~h}$ at $-0.5^{\circ} \mathrm{C}$ (Fig. $6 \mathrm{a})$, the film consisted of a $30 \mathrm{~nm}$ layer of $\mathrm{ZnO}$.

After $100 \mathrm{~h}$ at $-0.5^{\circ} \mathrm{C}$ (Fig. 6b), the $\mathrm{ZnO}$ film had grown in thickness and has become covered by a very thin layer of zinc hydroxy carbonate. The presence of $\mathrm{ZnO}$ is reminiscent of the STEM micrograph in Fig. 5c. In contrast, the films formed at $-1.0^{\circ} \mathrm{C}$ (Figs. 6c-6e) are dominated by sodium zinc carbonate, similar to the film in the STEM micrograph in Fig. $5 d$. The profile in Figure $6 \mathrm{~d}\left(-1^{\circ} \mathrm{C}\right)$ indicates the presence of a $\mathrm{Zn}(\mathrm{OH})_{2}$ layer between the zinc substrate and the sodium zinc carbonate layer.

Table II presents all the corrosion products detected by XRD, SEMSTEM/EDX and HR-AES. Simonkollite, hydrozincite, Zn carbonate hydroxide, sodium carbonates, and $\mathrm{ZnO}$ were identified at temperatures at $-0.5^{\circ} \mathrm{C}$ and higher, while sodium zinc carbonate, $\mathrm{Na}_{2} \mathrm{ZnCl}_{4} \cdot 3 \mathrm{H}_{2} \mathrm{O}$, zinc hydroxide (sweetite), and sodium carbonates were identified at $-1^{\circ} \mathrm{C}$ and below.

\section{Discussion}

Corrosion chemistry of $\mathbf{Z n}$.-When exposed to $\mathrm{O}_{2}$ or dry air at room temperature, $\mathrm{Zn}$ forms a passive film consisting of $\mathrm{ZnO}{ }^{27}$ Under the experimental conditions $\left(95 \% \mathrm{RH}\right.$ at $\left.-4^{\circ} \mathrm{C} \leq \mathrm{T} \leq 22^{\circ} \mathrm{C}\right)$, $\mathrm{NaCl}$ absorbs water and forms $\mathrm{NaCl}(a q)$ droplets on the surface. The $\mathrm{ZnO}$ film tends to be attacked by the aqueous solution, resulting in electrochemical corrosion. ${ }^{26,40}$ The anodic dissolution of $\mathrm{Zn}$ in acidic solution can be written:

$$
\mathrm{Zn}(\mathrm{s}) \rightarrow \mathrm{Zn}^{2+}(\mathrm{aq})+2 \mathrm{e}^{-}
$$

In neutral and slightly alkaline solution the reaction is:

$$
\mathrm{Zn}(\mathrm{s})+2 \mathrm{OH}^{-}(\mathrm{aq}) \rightarrow \mathrm{Zn}(\mathrm{OH})_{2}(\mathrm{aq})+2 \mathrm{e}^{-}
$$

Water reduction occurs in oxygen-free solution, $\mathrm{O}_{2}$ is the main oxidant in aerated solution: ${ }^{26}$

$$
1 / 2 \mathrm{O}_{2}(\mathrm{aq})+\mathrm{H}_{2} \mathrm{O}(\mathrm{l})+2 \mathrm{e}^{-} \rightarrow 2 \mathrm{OH}^{-}(\mathrm{aq})
$$

$\mathrm{Zn}$ dissolution causes chloride to accumulate in the anodic areas, the resulting $\mathrm{ZnCl}_{2}(a q)$ anolyte being somewhat acidic. Conversely, the migration of $\mathrm{Na}^{+}$ions to the cathodic areas result in the formation of a strongly alkaline $\mathrm{NaOH}(a q)$ catholyte. Being amphoteric, $\mathrm{ZnO}$ dissolves as zincate $\left(\mathrm{Zn}(\mathrm{OH})_{3}{ }^{-}(a q)\right)$ at very high $\mathrm{pH}(>12)$ and zinc is hence sensitive to corrosion at high $\mathrm{pH}$, see Thomas et al. ${ }^{22,25}$ However, under typical atmospheric corrosion conditions with very thin electrolyte layers and free access to $\mathrm{CO}_{2}$, the very high $\mathrm{pH}$ values needed for zincate formation are not expected to occur (see below).

Zincite $(\mathrm{ZnO})$ is an active substrate for the cathodic reduction of both $\mathrm{O}_{2}$ and $\mathrm{H}_{2} \mathrm{O},{ }^{24,41,42}$ its cathodic activity being directly dependent on its semiconducting properties. In contrast, most other corrosion products reported to form on $\mathrm{Zn}$ in the ambient atmosphere are large band-gap insulators, and, therefore cannot be efficient cathodes. 

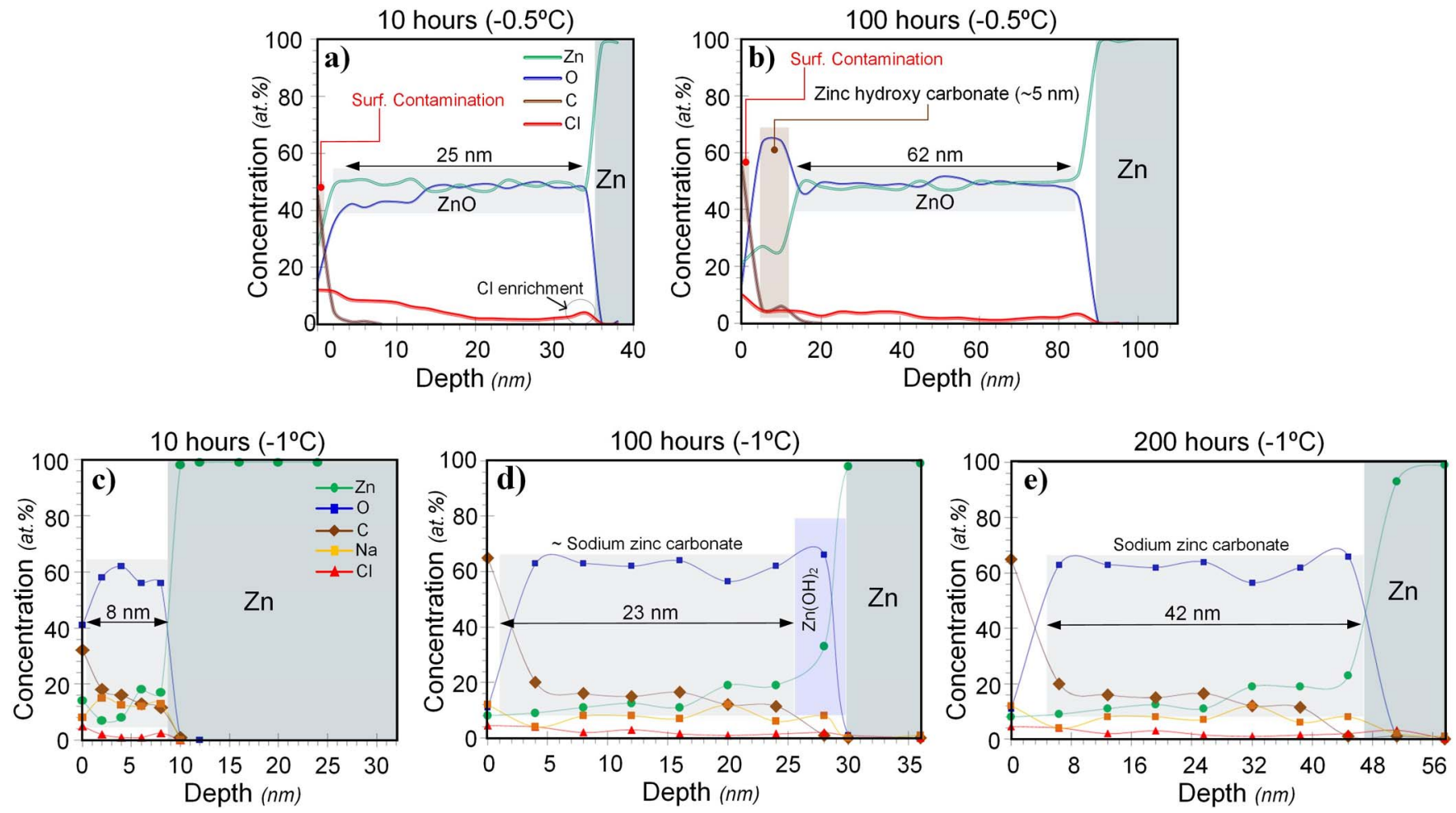

Figure 6. HR-AES compositional depth profiles (area: $200 \times 200 \mathrm{~nm}^{2}$ ) from the surface films formed on $\mathrm{Zn}$ at; $\left(\mathrm{a}\right.$ and b) $-0.5^{\circ} \mathrm{C}$ after $10 \mathrm{~h}$ and $100 \mathrm{~h}$, (c, d, and e) $-1{ }^{\circ} \mathrm{C}$ after $10 \mathrm{~h}, 100 \mathrm{~h}$ and $200 \mathrm{~h}$. Exposure parameters: $95 \% \mathrm{RH}, 400 \mathrm{ppm} \mathrm{CO}_{2}$, and $70 \mu \mathrm{g} / \mathrm{cm}^{2} \mathrm{NaCl}$.

This implies that $\mathrm{Zn}$ corrosion will be fundamentally influenced by the presence of $\mathrm{ZnO}$. On the wet $\mathrm{Zn} / \mathrm{ZnO}$ surface, $\mathrm{ZnO}$ can form by precipitation from a $\mathrm{Zn}^{2+}$ solution:

$$
\mathrm{Zn}^{2+}(\mathrm{aq})+2 \mathrm{OH}^{-}(\mathrm{aq}) \rightarrow \mathrm{ZnO}(\mathrm{s})+\mathrm{H}_{2} \mathrm{O}(\mathrm{l})
$$

In neutral solution, zincite is expected to precipitate, close to the anodic areas, from the supersaturated $\mathrm{Zn}(\mathrm{OH})_{2}(a q)$ solution produced by Reaction 2:

$$
\mathrm{Zn}(\mathrm{OH})_{2}(\mathrm{aq}) \rightarrow \mathrm{ZnO}(s)+\mathrm{H}_{2} \mathrm{O}(\mathrm{l})
$$

The precipitation of zinc hydroxide $\left(\mathrm{Zn}(\mathrm{OH})_{2}(s)\right)$ occurs by processes analogous to Reactions 4 and 5. Several zinc hydroxide allotropes are known, including three minerals; sweetite, ashoverite and wulfingite. ${ }^{43-45}$ It is important to note that zincite is reported to be more stable than the zinc hydroxides from the point of view of equilibrium thermodynamics. ${ }^{34}$ Therefore, direct conversion of zincite into zinc hydroxide is thermodynamically disallowed.

In the presence of air containing $\mathrm{CO}_{2}$ and water vapor, $\mathrm{ZnO}$ is reported to react to form zinc hydroxy carbonates, e.g., hydrozincite:

$$
\begin{gathered}
5 \mathrm{ZnO}(\mathrm{s})+2 \mathrm{CO}_{2}+3 \mathrm{H}_{2} \mathrm{O} \rightarrow \mathrm{Zn}_{5}\left(\mathrm{CO}_{3}\right)_{2}(\mathrm{OH})_{6}(\mathrm{~s}) \\
4 \mathrm{ZnO}(\mathrm{s})+\mathrm{CO}_{2}+4 \mathrm{H}_{2} \mathrm{O} \rightarrow \mathrm{Zn}_{4} \mathrm{CO}_{3}(\mathrm{OH})_{6} \cdot \mathrm{H}_{2} \mathrm{O}(\mathrm{s})
\end{gathered}
$$

In slightly acidic solution, zincite is readily converted to zinc hydroxide chloride, i.e., simonkolleite:

$$
5 \mathrm{ZnO}(\mathrm{s})+2 \mathrm{Cl}^{-}(\mathrm{aq})+2 \mathrm{H}^{+}+4 \mathrm{H}_{2} \mathrm{O}(\mathrm{l}) \rightarrow \mathrm{Zn}_{5}(\mathrm{OH})_{8} \mathrm{Cl}_{2} \cdot \mathrm{H}_{2} \mathrm{O}(\mathrm{s})
$$

\footnotetext{
Table II. Summary of phases detected by XRD, SEM/EDX and STEM/EDX after $1000 \mathrm{~h}$ exposure at the five temperatures, from 22 to $-4^{\circ} \mathrm{C}(\mathrm{Note}$ : the strength of the indications for the different compounds by the various methods of analysis is shown in the following way: Strong indication by XRD / a major constituent by SEM/EDX /a major constituent by STEM/EDX: +++, medium indication: ++, weak indication: +).
}

Phases identified
$\mathrm{Zn}_{5}(\mathrm{OH})_{8} \mathrm{Cl}_{2} \cdot \mathrm{H}_{2} \mathrm{O}$ (simonkolleite)
$\mathrm{Na}_{2} \mathrm{ZnCl}_{4} \cdot 3 \mathrm{H}_{2} \mathrm{O}$
$\mathrm{Na}_{2} \mathrm{Zn}_{3}\left(\mathrm{CO}_{3}\right)_{4} \cdot 3 \mathrm{H}_{2} \mathrm{O}$
$\mathrm{Zn}_{5}\left(\mathrm{CO}_{3}\right)_{2}(\mathrm{OH})_{6}$ (hydrozincite)
$\mathrm{Zn}_{4}\left(\mathrm{CO}_{3}\right)(\mathrm{OH})_{6} \mathrm{H}_{2} \mathrm{O}$
$\mathrm{Zn}(\mathrm{OH})_{2}$ (tetragonal) (sweetite)
$\mathrm{ZnO}(\mathrm{zincite})$
$\mathrm{Na}_{2} \mathrm{CO}_{3} x \mathrm{H}_{2} \mathrm{O}$ (sodium carbonate hydrate)
$\mathrm{NaHCO}_{3}$
$\mathrm{Zn}$
$\mathrm{NaCl}$

$\left(-0.5^{\circ} \mathrm{C} \leq \mathrm{T} \leq 22^{\circ} \mathrm{C}\right)$

$+++^{\mathrm{a}}$
-
-
$+^{\mathrm{a}}$
$+^{\mathrm{a}, \mathrm{e}}$
$-^{-}$
$+++^{\mathrm{d}, \mathrm{e}}$
$+^{\mathrm{c}}$
$+^{\mathrm{c}}$
$+^{\mathrm{a}}$

$\left(-4^{\circ} \mathrm{C} \leq \mathrm{T}<-0.5^{\circ} \mathrm{C}\right)$
${ }^{-}$
$+++^{\mathrm{d}, \mathrm{c}, \mathrm{d}, \mathrm{e}}$
-
-
$+^{\mathrm{a}, \mathrm{e}}$
${ }^{-}$
$+^{\mathrm{c}}$
$++^{\mathrm{a}}$
$+^{\mathrm{a}, \mathrm{c}}$

Note 1: a: detected by XRD; c: detected by SEM/EDX; d: detected by STEM/EDX; e: AES depth profiling. Note 2: $\mathrm{Na}_{2} \mathrm{CO}_{3} \cdot \mathrm{H}_{2} \mathrm{O}$ and NaHCO 3 were not directly identified but their presence was strongly supported by the analyses. 
Simonkolleite also forms by precipitation:

$$
\begin{aligned}
& 5 \mathrm{Zn}^{2+}(\mathrm{aq})+2 \mathrm{Cl}^{-}(\mathrm{aq})+8 \mathrm{OH}^{-}(\mathrm{aq})+\mathrm{H}_{2} \mathrm{O}(\mathrm{l}) \\
& \quad \rightarrow \mathrm{Zn}_{5}(\mathrm{OH})_{8} \mathrm{Cl}_{2} \cdot \mathrm{H}_{2} \mathrm{O}(\mathrm{s})
\end{aligned}
$$

In accordance with the electrochemical nature of corrosion, the present study shows that $\mathrm{Zn}$ corrosion is localized at all temperatures investigated, see SEM images in Fig. 4. The positive correlation between the amount of salt added and the rate of corrosion (Fig. 2) is attributed to the amount of surface electrolyte formed, which is proportional to the amount of added $\mathrm{NaCl}$.

The effect of temperature.- $\mathrm{A} \mathrm{NaCl}(a q)$ solution in equilibrium with $95 \% \mathrm{RH}$ at $22^{\circ} \mathrm{C}$ contains about $8.0 \%$ (wt\%) NaCl. ${ }^{47,48}$ Because the concentration of the $\mathrm{NaCl}(a q)$ electrolyte in equilibrium with $95 \%$ $\mathrm{RH}$ is almost independent of temperature in the experimental range, ${ }^{49}$ the amount and composition of the $\mathrm{NaCl}(a q)$ solution is essentially the same at all temperatures studied. Also, the solution does not form ice in the temperature range studied. ${ }^{50}$ Thus, the dependence of corrosion on temperature is not caused by differences in the amount or concentration of the electrolyte formed at the start of the experiment.

As mentioned in the introduction, there are few reports on the temperature dependence of the atmospheric corrosion of $\mathrm{Zn}$. Lindström et al. ${ }^{9}$ who investigated the $\mathrm{NaCl}$-induced atmospheric corrosion of $\mathrm{Zn}$ at 4,22 and $38^{\circ} \mathrm{C}$ reported no temperature dependence in the presence of $\mathrm{CO}_{2}$, but a strong positive correlation between corrosion rate and temperature in the absence of $\mathrm{CO}_{2}$. Svensson et al. ${ }^{24}$ reported that the rate of $\mathrm{SO}_{2}$-induced $\mathrm{Zn}$ corrosion exhibited an inverse temperature-dependence which was attributed to a somewhat protective zinc hydroxy sulfate precipitate that nucleated at high temperature but not at low temperature.

The present results show that the rate of $\mathrm{NaCl}$-induced corrosion of $\mathrm{Zn}$ in the presence of $\mathrm{CO}_{2}$ is independent of temperature in the range $-0.5-22^{\circ} \mathrm{C}$. In contrast, corrosion rate drops suddenly when temperature is lowered to $-1.0^{\circ} \mathrm{C}$ and below, see Fig. 2 and Fig. 4. The corrosion product composition is of special interest in the present study because the slower corrosion rate and change in corrosion morphology is accompanied by a drastic change in corrosion product composition (Table II). This suggests that there is a causal connection between corrosion rate and corrosion product composition. This hypothesis is explored in the following.

Corrosion at "high" temperatures $\left(-0.5^{\circ} \mathrm{C} \leq \mathrm{T} \leq 22^{\circ} \mathrm{C}\right)$. - The compounds identified after the exposures at high temperatures (Table II) have been previously reported as corrosion products on $\mathrm{Zn}$ in ambient air. Also, the analysis of the samples exposed at $-0.5,0.0$, $0.5^{\circ} \mathrm{C}$ indicated essentially the same composition. As noted in the introduction, hydrozincite and simonkolleite are ubiquitous in the atmospheric corrosion of $\mathrm{Zn}$, the latter often dominating in chloridecontaining environments. ${ }^{4}$ Falk et al. ${ }^{51}$ identified $\mathrm{Zn}_{4}\left(\mathrm{CO}_{3}\right)(\mathrm{OH})_{6} \mathrm{H}_{2} \mathrm{O}$ on $\mathrm{Zn}$ exposed to humid $\mathrm{CO}_{2}$-containing air and reported it to be metastable, being converted to hydrozincite with time. Zincite has been frequently reported as a corrosion product on $\mathrm{Zn},{ }^{24-26,52,53}$ while sodium carbonate and sodium hydrogen carbonate have been reported to form on $\mathrm{Zn}$ exposed to humid air in the presence of $\mathrm{NaCl}^{51,52}$

As noted above, $\mathrm{ZnO}$ is expected to play an important part in $\mathrm{Zn}$ corrosion, being an active cathode for $\mathrm{O}_{2}$ reduction. ${ }^{24,25}$ Indeed, the present study shows that a layer of zincite forms on the $\mathrm{Zn}$ surface at $-0.5^{\circ} \mathrm{C}$ and higher. For example, the cross section SEM/EDX (Fig. 5a) and STEM/EDX (Fig. 5c) $\left(22^{\circ} \mathrm{C}, 1000 \mathrm{~h}\right)$ images show a layered corrosion product where the upper part consist of agglomerated simonkolleite crystallites. The lower strata in the corrosion product consist of zincite, forming a very dense, $30-50 \mathrm{~nm}$, barrier-like layer in contact with the metal and a somewhat more porous layer immediately below the simonkolleite. Thus, at 4,10 and $22^{\circ} \mathrm{C}$, a large part of the corroding $\mathrm{Zn}$ surface is covered by a duplex $\mathrm{ZnO}$ layer. Notably, the STEM/EDX analysis of a cross section revealed traces of chloride in the "barrier" $\mathrm{ZnO}$ layer and chloride-rich corrosion pits in the $\mathrm{Zn}$ substrate, see Fig. 5c. Also, the HR-AES compositional depth profiles in Figs. 6a and $6 \mathrm{~b}\left(-0.5^{\circ} \mathrm{C}, 10 \mathrm{~h}, 100 \mathrm{~h}\right)$ show that a $\mathrm{ZnO}$ layer is rapidly established on the $\mathrm{Zn}$ substrate. Interestingly, the AES analysis shows a gradual buildup of zinc hydroxy carbonate layer on top of the $\mathrm{ZnO}$ layer which can be observed after $100 \mathrm{~h}$ at $-0.5^{\circ} \mathrm{C}$ (Fig. $6 \mathrm{~b})$. That layer has a composition similar to that of the metastable $\mathrm{Zn}_{4}\left(\mathrm{CO}_{3}\right)(\mathrm{OH})_{6} \cdot \mathrm{H}_{2} \mathrm{O}$ and, probably, formed according to Reaction 7 . The layer does contain some chloride and it is hypothesized that it may be converted to simonkolleite with time.

The corrosion morphology observed after $1000 \mathrm{~h}$ at 4,10 and $22^{\circ} \mathrm{C}$ is reminiscent of that reported by McDonald et al. ${ }^{54}$ who observed the formation of a duplex $\mathrm{ZnO}$ layer under anodic dissolution of $\mathrm{Zn}$ in alkaline solution. The duplex film consisted of a few nm thick, dense inner "barrier" $\mathrm{ZnO}$ layer, which, was proposed to have formed by a solid state reaction, and an outer, porous, $\mathrm{ZnO}$ layer precipitated from solution (see Reaction 5). The corrosion morphology is even more similar to that reported by Thomas et al. ${ }^{25}$ after $6 \mathrm{~h}$ exposure of $\mathrm{Zn}$ to a drop of seawater in air. They observed an outer macro-porous layer, covering a less porous $\mathrm{ZnO}$-containing middle layer and an about 50 $\mathrm{nm}$ thick, dense, $\mathrm{ZnO}$ bottom layer. Also, they observed chlorideinduced pitting below the $\mathrm{ZnO}$ layers. Thomas et al. ${ }^{24-26}$ present a corrosion scenario postulating that the $\mathrm{ZnO}$ layers contain pores that penetrate to the metal, metal dissolution in the pore being coupled to cathodic reduction of oxygen and water on the pore walls and on the metal.

In accordance with the work of Thomas et al., ${ }^{24,25}$ the corrosion morphology observed at 4,10 and $22^{\circ} \mathrm{C}$ is interpreted in terms of an electrochemical corrosion process in an aqueous electrolyte. Thus, although the bottom $\mathrm{ZnO}$ layer is seemingly dense, both $\mathrm{ZnO}$ sub-layers are considered to be permeable to the chloride-containing electrolyte. This implies that any "barrier" ZnO layer which may have been present at the start of the experiment is now penetrated by the aqueous electrolyte. $\mathrm{O}_{2}$ reduction (Reaction 3) occurs in the outer, porous, part of the $\mathrm{ZnO}$ layer $\left(\mathrm{O}_{2}\right.$ reduction at the $\mathrm{ZnO} /$ simonkolleite interface is not likely because simonkolleite is not compatible with the alkaline conditions in the catholyte). The cathodic process is coupled to the anodic dissolution of $\mathrm{Zn}$ (Reactions 1 and/or 2 below the $\mathrm{ZnO}$ layer. This is consistent with the growth of a $\mathrm{ZnO}$ layer by precipitation (Reactions 4 and 5. The reduction of $\mathrm{O}_{2}$ within the $\mathrm{ZnO}$ layer requires the simonkolleite layer to be permeable to $\mathrm{O}_{2}$ transport, in agreement with its observed porosity. Significant water reduction in the pits, as suggested by Zhang ${ }^{55}$ would tend to re-passivate the $\mathrm{Zn}$ surface and is therefore deemed less likely. Thus, the relatively fast corrosion in the range $-0.5-22^{\circ} \mathrm{C}$ is related to the formation of a poorly protective zincite layer which acts as catalyst for cathodic $\mathrm{O}_{2}$ reduction. Accordingly, it has been reported that $\mathrm{ZnO}$ layers formed at $\mathrm{pH}<12$ tend not to passivate the metal in the presence of chloride. ${ }^{56}$

The present finding that the rate of corrosion of $\mathrm{Zn}$ is independent of temperature when exposed at $>-0.5^{\circ} \mathrm{C}$, in the presence $\mathrm{CO}_{2}$, is in accordance with Lindström et al. ${ }^{16}$ In contrast, the same authors ${ }^{16}$ reported a strong positive temperature dependence of corrosion in the absence of $\mathrm{CO}_{2}$, suggesting that the lack of temperature dependence is connected to $\mathrm{CO}_{2}$. Also, Falk et al. ${ }^{51}$ reported that $\mathrm{CO}_{2}$ inhibits $\mathrm{Zn}$ corrosion. In agreement with others, ${ }^{9,20}$ it is considered that the observed trend is connected to the inhibitive effect of $\mathrm{CO}_{2}$, which, in turn, depends on the formation of carbonic acid. It may be noted that while the solubility of $\mathrm{CO}_{2}$ increases with decreasing temperature, the conversion of $\mathrm{CO}_{2}(a q)$ to carbonic acid is a slow, thermally activated process. ${ }^{39,57}$ It is hypothesized that the two antagonistic temperature dependencies cancel out, explaining the lack of temperature dependence of corrosion in the range $-0.5-22^{\circ} \mathrm{C}$.

Corrosion at "low" temperatures $\left(-4^{\circ} \mathrm{C} \leq \mathrm{T}<-0.5^{\circ} \mathrm{C}\right)$. - The corrosion products formed at low temperatures were very different from those generated at "high" temperature (Table II), sodium carbonate being the only product occurring regardless of temperature. The dominant corrosion product was sodium zinc carbonate, $\mathrm{Na}_{2} \mathrm{Zn}_{3}\left(\mathrm{CO}_{3}\right)_{4} \cdot 3 \mathrm{H}_{2} \mathrm{O}$ (XRD results in Fig. 3, STEM in Fig. 5d, and AES profiles in Figs. 6c-6e). This compound was previously detected by Ortiz et al. ${ }^{58}$ on $\mathrm{Zn}-\mathrm{Mn}$ coated steel subjected to salt spray 
testing. In addition, Prosek et al. ${ }^{59}$ suggested that it formed on $\mathrm{Zn}$ plated steel exposed to humid air/ $\mathrm{NaCl}$. In both cases, the compound was reported to form at ambient temperature or higher. The present study apparently is the first to positively identify sodium zinc carbonate as the principal corrosion product of $\mathrm{Zn}$.

Sweetite, a tetragonal form of $\mathrm{Zn}(\mathrm{OH})_{2}$, was also only detected after the low temperature exposures. While wulfingite $\left(\varepsilon-\mathrm{Zn}(\mathrm{OH})_{2}\right)$ has been reported as a corrosion product previously, ${ }^{60}$ the present study appears to be the first to identify sweetite as a corrosion product. As noted above, crystalline zinc hydroxides are reported to be more soluble than $\mathrm{ZnO} .{ }^{55,61}$ Hence, the formation of sweetite is attributed to kinetics and not to equilibrium thermodynamics. Accordingly, it is proposed that the nucleation of sweetite is faster than zincite at low temperature. In addition to the identification of sweetite by XRD, the presence of zinc hydroxide at low temperature is also evidenced by the AES analysis in Fig. 6d showing a $\mathrm{Zn}(\mathrm{OH})_{2}$ layer which is sandwiched between $\mathrm{Na}_{2} \mathrm{Zn}_{3}\left(\mathrm{CO}_{3}\right)_{4} \cdot 3 \mathrm{H}_{2} \mathrm{O}$ and the $\mathrm{Zn}$ substrate. The close association of the two compounds suggests that sodium zinc carbonate is formed by the reaction of zinc hydroxide with the surface electrolyte:

$$
\begin{gathered}
3 \mathrm{Zn}(\mathrm{OH})_{2}(\mathrm{~s})+\mathrm{NaHCO}_{3}(\mathrm{aq})+2 \mathrm{CO}_{2}(\mathrm{aq}) \\
\rightarrow \mathrm{Na}_{2} \mathrm{Zn}_{3}\left(\mathrm{CO}_{3}\right)_{4} \cdot 3 \mathrm{H}_{2} \mathrm{O}(\mathrm{s})+\mathrm{H}_{2} \mathrm{O}(\mathrm{l})
\end{gathered}
$$

The third "low" temperature corrosion product detected was $\mathrm{Na}_{2} \mathrm{ZnCl}_{4} \cdot 3 \mathrm{H}_{2} \mathrm{O}$, which was identified by STEM/EDX. Prosek et al. ${ }^{41}$ tentatively identified it as one of several corrosion products on a ZnAlSi alloy exposed to humid air and $\mathrm{NaCl}$ at $20^{\circ} \mathrm{C}$. $\mathrm{Na}_{2} \mathrm{ZnCl}_{4} \cdot 3 \mathrm{H}_{2} \mathrm{O}$ is highly soluble in water and needs high concentrations of $\mathrm{NaCl}(a q)$ in order to precipitate from solution. ${ }^{42}$ This is in accordance with the identification of unreacted $\mathrm{NaCl}(a q)$ after the exposure. Also, $\mathrm{Na}_{2} \mathrm{ZnCl}_{4} \cdot 3 \mathrm{H}_{2} \mathrm{O}$ is hydrolyzed in neutral or alkaline conditions, revealing that slightly acidic conditions prevail on parts of the corroding surface.

To summarize, the corrosion products generated by the relatively rapid corrosion at "high" temperatures were dominated by simonkolleite and $\mathrm{ZnO}$ together with small amounts of zinc hydroxy carbonates, while the slower corrosion at "low" temperatures was associated with a corrosion product where simonkolleite, $\mathrm{ZnO}$, and crystalline zinc hydroxy carbonates were absent. Instead, sodium zinc carbonate $\left(\mathrm{Na}_{2} \mathrm{Zn}_{3}\left(\mathrm{CO}_{3}\right)_{4}\left(\mathrm{H}_{2} \mathrm{O}\right)_{3}\right)$ dominated along with smaller amounts of sweetite $\left(\mathrm{Zn}(\mathrm{OH})_{2}\right)$ and $\mathrm{Na}_{2} \mathrm{ZnCl}_{4} \cdot 3 \mathrm{H}_{2} \mathrm{O}$.

Accordingly, the STEM image after "low" temperature exposure (Fig. 5d) shows a thick sodium zinc carbonate layer on the surface. In addition, the AES analysis (Fig. 6D) reveals the presence of a thin zinc hydroxide layer between zinc and the sodium zinc carbonate layer. Similar to the duplex $\mathrm{ZnO}$ layer formed at "high" temperatures, the $\mathrm{Na}_{2} \mathrm{Zn}_{3}\left(\mathrm{CO}_{3}\right)_{4}\left(\mathrm{H}_{2} \mathrm{O}\right)_{3} / \mathrm{Zn}(\mathrm{OH})_{2}$ layer seems dense but is apparently permeable to chloride ions, as evidenced by the linear chlorine gradient through it and by the presence of chlorine-enriched corrosion pits in the metal. The observations strongly suggest that corrosion is electrochemical also in this case.

Because both $\mathrm{Na}_{2} \mathrm{Zn}_{3}\left(\mathrm{CO}_{3}\right)_{4}\left(\mathrm{H}_{2} \mathrm{O}\right)_{3}$ and $\mathrm{Zn}(\mathrm{OH})_{2}$ are large bandgap insulators, the layer covering the $\mathrm{Zn}$ surface cannot be cathodically active. Hence, the cathode must be situated at a distance from the anodic sites, presumably in the vicinity of the sodium carbonate precipitates observed in plan-view (Point 4 in Fig. 4d). While zincite was not observed, the cathodic activity is suggested to be associated with $\mathrm{ZnO}$ also in this case, e.g., to remnants of the air-formed $\mathrm{ZnO}$ surface film present at the start of the exposure. The presence of unreacted $\mathrm{NaCl}$ after the exposure shows that there is ample electrolyte on the surface to support such a process.

Comparing the "low" and "high" temperature corrosion modes.- The discussion above shows that the mechanism of $\mathrm{Zn}$ corrosion at low temperature $\left(-4^{\circ} \mathrm{C} \leq \mathrm{T} \leq-1^{\circ} \mathrm{C}\right)$ is fundamentally different from corrosion at higher temperature $\left(-0.5^{\circ} \mathrm{C} \leq \mathrm{T} \leq 22^{\circ} \mathrm{C}\right)$. This difference is attributed to the occurrence of $\mathrm{ZnO}$. As mentioned above, the zinc hydroxides are more soluble and thus less stable than
$\mathrm{ZnO}$, according to equilibrium thermodynamics. Thus, the replacement of $\mathrm{ZnO}$ by zinc hydroxide (sweetite) at low temperature must be explained by kinetics, in this case the rate of nucleation of two solids. Thus, the lack of direct evidence for $\mathrm{ZnO}$ and the identification of sweetite $\left(\mathrm{Zn}(\mathrm{OH})_{2}\right)$ at low temperature implies that, even though $\mathrm{ZnO}$ is thermodynamically stable on the corroding surface at all temperatures studied, zincite precipitation is inhibited at $-1{ }^{\circ} \mathrm{C}$ and below. The temperature dependence of zincite precipitation is not unexpected, considering that the nucleation of a phase is always thermally activated.

Therefore, at "low" temperature, zincite is replaced by $\mathrm{Zn}(\mathrm{OH})_{2}(s)$ which is electronically insulating and therefore cannot play the role of cathode. The AES analysis of the corrosion product layer formed after $100 \mathrm{~h}$ at low temperature (Fig. 6d) shows a thin zinc hydroxide film sandwiched between the metal and the sodium zinc carbonate layer.

We believe that he zinc hydroxide layer formed initially and that the sodium zinc carbonate formed from it (see Reaction 10). In this way a situation arises where the zinc anode becomes spatially separated from the cathode by a layer of corrosion products, which is cathodically inactive. It may be noted that while the duplex zincite layer formed at higher temperatures (Fig. 5c) and the sodium zinc carbonate $/ \mathrm{Zn}(\mathrm{OH})_{2}$ layer formed at low temperature (Figs. 5d and 6d) are both apparently permeable to chloride ions and water, allowing the anodic dissolution of the $\mathrm{Zn}$ substrate, the two layers differ a lot in properties. Importantly, zincite is an active cathode for $\mathrm{O}_{2}$ reduction, while both zinc hydroxide and sodium zinc carbonate are electronic insulators and cannot act as cathodes. Consequently, in the low temperature mode of corrosion, the anodic dissolution of zinc below the electronically insulating layer is presumably coupled to cathodic $\mathrm{O}_{2}$ reduction on parts of the surface where the original $\mathrm{ZnO}$ film remains. In contrast, the high temperature form of corrosion is characterized by the close proximity of anodic and cathodic surfaces, the poorly protective zincite layer acting as substrate for cathodic $\mathrm{O}_{2}$ reduction.

This study shows that the peculiar temperature dependence of the atmospheric corrosion of $\mathrm{Zn}$ is not due to some activated process (e.g., charge transfer or ionic conduction) limiting the rate of a single corrosion process. Instead, it is due to a change in the mechanism of corrosion which is temperature related.

The present results, showing that the "low" temperature corrosion mode is significantly slower than the "high" temperature mode, are notable considering that the $\mathrm{NaCl}(a q)$ electrolyte was consumed by formation of simonkolleite and sodium carbonate at "high" temperature while it remained throughout the exposure at "low" temperature. Tentatively, the slower corrosion at low temperature is attributed to the greater separation of anode and cathode in the electrochemical corrosion cell.

The lack of temperature-dependence of corrosion in the high temperature range was discussed above. The low-temperature corrosion mode was observed in several experiments $\left(-1,-1.5,-2,-4{ }^{\circ} \mathrm{C}, 14\right.$ and $70 \mu \mathrm{g} / \mathrm{cm}^{2}$ of $\mathrm{NaCl}$ ). While the small range of temperatures does not allow us to draw definite conclusions regarding the temperaturedependence of the low temperature corrosion mode, the observed positive temperature dependence of corrosion at low temperature suggests that corrosion rate in this regime is limited by one or more activated processes.

In summary, the peculiar temperature dependence of the rate of $\mathrm{NaCl}$-induced atmospheric corrosion of $\mathrm{Zn}$ is attributed to a change in corrosion mechanism that occurs between -0.5 and $-1{ }^{\circ} \mathrm{C}$. The change in corrosion mechanism, in turn, is caused by the replacement of $\mathrm{ZnO}$ by $\mathrm{Zn}(\mathrm{OH})_{2}$ at low temperature. The present findings may prove useful for interpreting the atmospheric corrosion of $\mathrm{Zn}$ and Zn-plated steel in automotive applications where the materials are exposed to $\mathrm{NaCl}$ at low temperature and high humidity.

All in all, addressing the properties of the corrosion product layer, i.e., sodium zinc carbonate $\left(\mathrm{Na}_{2} \mathrm{Zn}_{3}\left(\mathrm{CO}_{3}\right)_{4} \cdot 3 \mathrm{H}_{2} \mathrm{O} / \mathrm{Zn}(\mathrm{OH})_{2}\right)$ and the characteristic of the relatively slow "low" temperature corrosion mode may open up an opportunity to improve the atmospheric corrosion behavior of $\mathrm{Zn}$. Therefore, one exciting future research track would be 
to investigate whether the corrosion behavior of $\mathrm{Zn}$ may be improved via promoting the formation of such layers. This would involve investigating how such layers can be formed in an appreciable amount at room temperature and higher, enabling their application under "real" service conditions.

\section{Conclusions}

We studied the $\mathrm{NaCl}$-induced atmospheric corrosion of $\mathrm{Zn}$ at different temperatures in the range -4 to $22^{\circ} \mathrm{C}$. Measurements of the corrosion rate and analysis of the composition/morphology of corrosion products formed allowed us to draw the following main conclusions:

- While the $\mathrm{NaCl}$-induced atmospheric corrosion of $\mathrm{Zn}$ was independent of temperature in the range $-0.5-22^{\circ} \mathrm{C}$, corrosion rate dropped significantly at $-1.0,-1.5,-2$ and especially, at $-4^{\circ} \mathrm{C}$.

- The peculiar temperature dependence of the rate of $\mathrm{NaCl}$ induced atmospheric corrosion of zinc is attributed to a change in corrosion mechanism that occurs between -1.0 and $-0.5^{\circ} \mathrm{C}$.

- The "high" temperature mode of corrosion (at $-0.5^{\circ} \mathrm{C}$ and higher) is characterized by the formation of a poorly protective $\mathrm{ZnO}$ layer on the surface. Cathodic $\mathrm{O}_{2}$ reduction occurs in pores in the $\mathrm{ZnO}$ layer while anodic dissolution of $\mathrm{Zn}$ occurs below the $\mathrm{ZnO}$ layer. In this corrosion mode the principal corrosion products were hydrozincite, simonkolleite and $\mathrm{ZnO}$.

- At $-1.0^{\circ} \mathrm{C}$ and below, $\mathrm{ZnO}$ was replaced by $\mathrm{Zn}(\mathrm{OH})_{2}$. Corrosion resulted in the zinc surface being covered by a sodium zinc carbonate $\left(\mathrm{Na}_{2} \mathrm{Zn}_{3}\left(\mathrm{CO}_{3}\right)_{4} \cdot 3 \mathrm{H}_{2} \mathrm{O}\right) / \mathrm{Zn}(\mathrm{OH})_{2}$ layer. While this layer is permeable to chloride ions and water, it is electronically insulating. This results in a separation of the anode below the layer and the cathode on other parts of the metal surface. The main corrosion products in the low temperature corrosion mode were $\mathrm{Na}_{2} \mathrm{Zn}_{3}\left(\mathrm{CO}_{3}\right)_{4} \cdot 3 \mathrm{H}_{2} \mathrm{O}$, $\mathrm{Zn}(\mathrm{OH})_{2}$ (sweetite) and $\mathrm{Na}_{2} \mathrm{ZnCl}_{4} \cdot 3 \mathrm{H}_{2} \mathrm{O}$. This is the first identification of sweetite as a corrosion product.

- While the rate of the high temperature mode of corrosion was temperature independent, the low temperature corrosion mode showed a positive correlation with temperature.

\section{Acknowledgment}

We would like to deeply thank Professor Polina Volovitch (Chimie ParisTech, France) and Dr. Mats Ström (Volvo Car Cooperation) for helpful discussion. Also, we appreciate the Swedish Foundation for Strategic Research (SSF) (grant number: RMA08-0138) and the Swedish Research Council (Vr) (grant number: 2015-04977) for funding this research.

\section{References}

1. A. R. Marder, Prog. Mater. Sci., 45, 191 (2000).

2. T. E. Graedel, J. Electrochem. Soc., 136, 193C (1989).

3. Y. Sato and K. Azumi, J. Electrochem. Soc., 162, C509 (2015).

4. D. Thierry and D. Massinon, J. Electrochem. Soc., 138, 879 (1991).

5. T. Prosek, A. Nazarov, and D. Thierry, Prog. Organ. Coat., 101, 45 (2016).

6. T. Prosek, A. Nazarov, H. B. Xue, and S. Lamaka, Prog. Organ. Coat., 99, 356 (2016).

7. D. de la Fuente, J. G. Castano, and M. Morcillo, Corros. Sci., 49, 1420 (2007).

8. J. G. Castano, D. de la Fuente, and M. Morcillo, Atmos. Environ., 41, 8681 (2007).

9. F. Zhu, D. Persson, D. Thierry, and C. Taxen, Corrosion, 56, 1256 (2000).

10. X. Zhang, C. Leygraf, and I. O. Wallinder, Corros. Sci., 73, 62 (2013).

11. N. S. Azmat, K. D. Ralston, B. C. Muddle, and I. S. Cole, Corros. Sci., 53, 1604 (2011)
12. Z. Y. Chen, D. Persson, and C. Leygraf, Corros. Sci., 50, 111 (2008).

13. D. D. Macdonald, K. M. Ismail, and E. Sikora, J. Electrochem. Soc., 145, 3141 (1998).

14. J. D. Yoo, K. Ogle, and P. Volovitch, Corros. Sci., 81, 11 (2014).

15. P. Volovitch, C. Allely, and K. Ogle, Corros. Sci., 51, 1251 (2009).

16. R. Lindström, J. E. Svensson, and L. G. Johansson, J. Electrochem. Soc., 147, 1751 (2000).

17. I. Odnevall and C. Leygraf, Atmospheric Corrosion, ASTM STP 1239, Philadelphia, 215 (1995).

18. I. Odnevall and C. Leygraf, Corros. Sci., 36, 1551 (1994).

19. J. E. Svensson and L. G. Johansson, J. Electrochem. Soc., 140, 2210 (1993).

20. R. Lindström, J. E. Svensson, and L. G. Johansson, J. Electrochem. Soc., 149, B57 (2002).

21. B. Sanyal and D. V. Bhadwar, J. Sci. Ind. Res., 21D, 243 (1962).

22. S. Thomas, N. Birbilis, M. S. Venkatraman, and I. S. Cole, Corrosion, 68, 015009 (2012).

23. S. Thomas, I. S. Cole, and N. Birbilis, J. Electrochem. Soc., 160, C59 (2012).

24. S. Thomas, I. S. Cole, M. Sridhar, and N. Birbilis, Electrochim. Acta., 97, 192 (2013).

25. S. Thomas, N. Birbilis, M. S. Venkatraman, and I. S. Cole, Corros. Sci., 69, 11 (2013).

26. S. Thomas, I. S. Cole, Y. Gonzalez-Garcia, M. Chen, M. Musameh, J. M. C. Mol, H. Terryn, and N. Birbilis, J. Appl. Electrochem., 44, 747 (2014).

27. J. Elvins, J. A. Spittle, J. H. Sullivan, and D. A. Worsley, Corros. Sci., 50, 1650 (2008).

28. T. Prosek, J. Hagström, D. Persson, N. Fuertes, F. Lindberg, O. Chocholatý, C. Taxén, J. Šerák, and D. Thierry, Corros. Sci., 110, 71 (2016).

29. R. Krieg, A. Vimalanandan, and M. Rohwerder, J. Electrochem. Soc., 161, C156 (2014).

30. J. D. Yoo, K. Ogle, and P. Volovitch, Corros. Sci., 81, 11 (2014).

31. P. Volovitch, C. Allely, and K. Ogle, Corros. Sci., 51, 1251 (2009).

32. F. C. Porter, Corrosion Resistance of Zinc and Zinc Alloys, Verlag Marcel Dekker Inc. New York, 1994.

33. P. Kofstad, High Temperature Oxidation of Metals, John Wiley \& Sons, 1966.

34. D. B. Blücher, J. E. Svensson, and L. G. Johansson, J. Electrochem. Soc., 140, 2210 (1993).

35. A. Niklasson, L. G. Johansson, and J. E. Svensson, Corros. Sci., 50, 3031 (2008).

36. M. Esmaily, D. B. Blücher, J. E. Svensson, M. Halvarsson, and L. G. Johansson, Scrip. Mater. 115, 91 (2016)

37. J. E. Svensson and L. G. Johansson, Corros. Sci., 38, 2225 (1996).

38. J. F. Henriksen and A. Rode, Proceedings of 10th Scandinavian Corrosion Congress, Sweden, 1986.

39. M. Esmaily, M Shahabi-Navid, J. E. Svensson, M. Halvarsson, L. Nyborg, Y. Cao, and L. G. Johansson, Corros. Sci., 90, 420 (2015)

40. I. S. Cole, T. H. Muster, D. Lau, N. Wright, and N. S. Azmat, J. Electrochem. Soc., 157, C213 (2010).

41. A. Goux, T. Pauporte, and D. Lincot, Electrochim. Acta, 51, 3168 (2006).

42. H. J. Flitt and D. P Schweinsberg, Corros. Sci., 52, 1905 (2010).

43. A. M. Clark, E. E. Fejer, G. Cressey, and P. C. Tandy, Mineral. Mag., 52, 699 (1988).

44. A. M. Clark, E. E. Fejer, A. G. Couper, and G. C. Jones, Mineral. Mag., 48, 267 (1984).

45. K. Schmetzer, G. Schnorrer-Kohler, and O. Medenbach, Neues. Jahrb. Mineral. Mh. 145 (1985).

46. R. Grauer and W. Feitknecht, Corros. Sci., 7, 643 (1967).

47. R. A. Robinson and R. H. Stokes, Electrolyte Solutions, Butterworths, London, 1965.

48. K. S. Pitzer, J. Phys. Chem., 77, 268 (1973).

49. M. J. Blandamer, J. B. Engberts, P. T. Gleeson, and J. C. Reis, Chem. Soc. Rev, , 34, 440 (2005).

50. R. J. Bodnar, Geochim. Cosmochim. Acta, 57, 683 (1993).

51. T. Falk, J. E. Svensson, and L. G. Johansson, J. Electrochem. Soc., 145, 2993 (1998).

52. R. Grauer, Mater. Corros. (Werkst. Korros.), 31, 837 (1980).

53. T. Prosek, D. Persson, J. Stoulil, and D. Thierry, Corros. Sci., 86, 231 (2014).

54. D. D. Macdonald, K. M. Ismail, and E. Sikora, J. Electrochem. Soc., 145, 3141 (1998).

55. X. G. Zhang, Corrosion and Electrochemistry of Zinc, Springer Science, New York, 1996.

56. A. P. Yadav, A. Nishikata, and T. Tsuru, J. Electroanal. Chem., 585, 142 (2005).

57. M. Shahabi, M. Esmaily, J. E. Svensson, M. Halvarsson, L. Nyborg, Y. Cao, and L. G. Johansson, J. Electrochem. Soc., 161, C277 (2014).

58. Z. I. Ortiz, P. Díaz-Arista, Y. Meas, R. Ortega-Borges, and G. Trejo, Corros. Sci., 51, 2703 (2009).

59. T. Prosek, D. Thierry, C. Taxén, and J. Maixner, Corros. Sci., 49, 2676 (2007).

60. R. Grauer and H. Kaesche, Corros. Sci., 12, 617 (1972).

61. V. V. Danilov, A. A. Ravdel, and V. P. Lutsik, J. Gen. Chem. USSR., 46, 973 (1976).

62. E. V. Belova, M. N. Mamontov, and I. A. Uspenskaya, J. Chem. Eng. Data, 61, 2426 (2016). 